\section{Social Work \& Education}

CSW\&E, 2021

\author{
УДК $\quad 378.018 .8: 364.4-051]:[364.4-$ \\ 053.6:378.4(477.46)УДПУ]
}

DOI: $10.25128 / 2520-6230.21 .3 .4$

Левченко, Н. (2021). Зміст підготовки майбутніх соціальних працівників до молодіжної роботи: $з$ досвіду Уманського державного педагогічного університету імені Павла Тичини. Social Work and Education, Vol. 8, No. 3. pp. 352-363. DOI: $10.25128 / 2520-6230.21 .3 .4$

\title{
ЗМІСТ ПІДГОТОВКИ МАЙБУТНІХ СОЦІАЛЬНИХ ПРАЦІВНИКІВ ДО МОЛОДІЖНОЇ РОБОТИ: 3 ДОСВІДУ УМАНСЬКОГО ДЕРЖАВНОГО ПЕДАГОГІЧНОГО УНІВЕРСИТЕТУ ІМЕНІ ПАВЛА ТИЧИНИ
}

\begin{abstract}
Наталія Левченко, кандидат педагогічних наук, доцент кафедри соціальної педагогіки та соціальної роботи, докторант Уманського державного педагогічного університету імені Павла Тичини; м. Умань, Україна;

n.levchenkod@gmail.com
\end{abstract}

ORCID ID: http://orcid.org/00000002-5479-1907

\section{Cmamyc cmammi:}

Отримано: серпень 05, 2021

1-иерецензувания: вересень 07, 2021

Прийнято: вересень 30, 2021
Анотація. Сучасна молодь $є$ предметом особливої уваги сучасного суспільства, тому що зміна соціальноекономічної і політичної системи України здійснила неоднозначний вплив на свідомість i поведінку підростаючого покоління. Нині у різних сферах життя спостерігаються демократичні процеси, відбувається розбудова громадянського суспільства, надаються широкі можливості розвитку особистості, прояву ініціативи і творчості. Майбутнє держави багато в чому залежить від громадянської позиції підростаючого покоління, тому це підвищує значущість управління процесами національнопатріотичного становлення майбутніх соціальних працівників до молодіжної роботи в процесі навчання у закладі вищої освіти. Мета статті - проаналізувати специфіку освітньо-професійної програми «Соціальна робота (Молодіжна робота)» для підготовки майбутніх соціальних працівників до молодіжної роботи в Уманському державному педагогічному університеті імені Павла Тичини. У статті висвітлено актуальність впровадження в освітній процес підготовки майбутніх соціальних працівників до молодіжної роботи навчальних дисциплін «Теорія i практика молодіжної роботи», «Молодь у сучасній громаді»; розкрито зміст і структуру обов'язкових навчальних компонентів освітньопрофесійної програми «Соціальна робота (Молодіжна робота)»; подано методи навчання та викладання, критерії оцінювання програмних результатів навчання; виокремлено та проаналізовано загальні, фахові компетентностей i програмні результати навчання - регламентовані навчальними дисциплінами. Визначено особливості освітньої програми для підготовки майбутніх соціальних працівників до молодіжної роботи 3 досвіду факультету соціальної та психологічної освіти Уманського державного педагогічного університету імені Павла Тичини.

Ключові слова: майбутні соціальні працівники; молодіжні працівники; молодіжна робота; освітньопрофесійна програма; соціальна робота. 


\section{Вступ}

Державна політика у сфері вищої освіти грунтується на принципі сприяння сталому розвитку суспільства шляхом підготовки конкурентоспроможного людського капіталу та створення умов для освіти протягом життя (ЗУ «Про вищу освіту», 2014). Згідно із Законом України «Про вищу освіту» (2014) підготовка здобувачів вищої освіти здійснюється відповідно до стандартів вищої освіти - це сукупність вимог до освітніх програм вищої освіти, які є спільними для всіх освітніх програм у межах певного рівня вищої освіти та спеціальності (ЗУ «Про вищу освіту», 2014). Відповідно до стандарту вищої освіти спеціальності заклад вищої освіти розробляє освітню програму, що визначає структуру, зміст освіти, організації освітнього процесу, компетентності, програмні результати навчання, перелік та обсяг освітніх компонентів, атестації випускників та навчальний план, що включає перелік, обсяг освітніх компонентів, їх логічну послідовність, форми організації освітнього процесу, види та обсяг навальних занять, графік освітнього процесу, форми поточного і підсумкового контролю. Тому, закладам вищої освіти при наданні освітніх послуг у підготовці майбутніх соціальних працівників потрібно дотримуватись державні вимоги, враховувати державні стандарти вищої освіти при розробці освітніх програм зі спеціальності 231 Соціальна робота. Згідно зі Стандартом визначено цілі навчання: підготовка фахівців, здатних розв’язувати складні завдання і проблеми соціальної сфери або у процесі навчання, що передбачає проведення дослідження та/або здійснення інновацій та характеризується невизначеністю умов і вимог.

Основне завдання підготовки майбутніх соціальних працівників у закладах вищої освіти - формування їхньої професійної компетентності завдяки: освітньопрофесійнім програмам спрямованим на формування загальних та фахових компететностей і досягнення програмних результатів навчання, необхідних для професійної діяльності; реалізації робочих програм навчальних дисциплін 3 урахуванням сучасних вимог суспільства до фахівців соціальної та молодіжної сфер; та удосконалення практичних навичок професійної підготовки майбутніх фахівців (Kravchenko, Koliada, Levchenko, 2020).

Об'єктами вивчення майбутніх соціальних працівників під час підготовки до професійної діяльності є соціальний добробут населення, детермінанти, що на нього впливають; організаційна, управлінська, експертна, контрольно-аналітична, проектна, науково-дослідна діяльність у соціальній сфері.

Теоретико-методичні та практичні основи підготовки майбутніх соціальних працівників відображаються в наукових доробках вітчизняних i зарубіжних учених (В. Андрющенко, О. Безпалько, М. Євтух, А. Капська, 3. Бондаренко, Р. Вайнола, Ю. Галагузова, О. Гудима, І. Звєрєва, Л. Онуфрієва, О. Карпенко, Л. Коваль, В. Поліщук, Л. Міщик, Т. Семігіна, Д. Фельдштейн та ін.), які акцентують на структурних компонентах моделі особистості майбутнього соціального працівника, на вимогах до його знань, умінь і навичок професійної діяльності, особливостях формування готовності до роботи з певною категорією населення (Коляда, 2020).

Наукову проблему професійної підготовки майбутніх соціальних працівників у ЗВО на основі застосування контекстного підходу у своїх працях 
висвітлює Г. Слозанська. Авторка зазначає, що правильне та ефективне планування і реалізація активних форм та методів контекстного навчання під час опанування професійно-орієнтованих навчальних дисциплін дозволяє здобувачу вищої освіти спеціальності 231 Соціальна робота зануритися у майбутню професійну діяльність; отримати нові знання даної спеціальності; стимулювати розвиток пізнавальних інтересів; проаналізувати та спроєктувати технологію вирішення реальних професійних ситуацій, змоделювати життєві та виробничі ситуації; сформувати позитивну мотивацію до навчання та усвідомити власні цілі в процесі оволодіння майбутньою професією (Слозанська, 2016).

Аспекти професійної підготовки майбутніх працівників соціальної сфери розглянуто в дослідженні Л. Міщик, де розкрито теоретико-методичні основи підготовки майбутніх фахівців у закладах вищої освіти. У дослідженні Р. Вайноли вивчено особливості особистісного розвитку майбутнього соціального педагога під час професійної підготовки. Вітчизняні науковці дослідили такі важливі питання, як формування професійної готовності до взаємодії 3 девіантною молоддю (С. Толстоухова), особливості роботи з громадськими та молодіжними організаціями (О. Гудима, І. Мигович). В. Бех, М. Лукашевич, І. Пінчук вивчають зв'язок соціальної роботи та розвиток громадського суспільства, акцентуючи увагу на ролі соціальної роботи у становленні суспільства та соціальної держави (Коляда, Левченко та Ісаченко, 2020).

Концепції змісту, організаційних форм і технологій навчання в закладах вищої освіти досліджували С. Архангельський, В. Беспалько, А. Вербицький, С. Харченко; провідні ідеї, положення наукових досліджень, присвячених історії становлення та розвитку дитячого та молодіжного руху на території України - I. Андрухів, В. Головенько, Б. Савчук та ін.; теорію та методику організації діяльності сучасних громадських дитячих та молодіжних об'єднань - Л. Алієва, А. Волохов, Р. Литвак, Ю. Поліщук, І. Фрішман та ін. (Коляда, Левченко та Ісаченко, 2020).

Підготовку майбутніх соціальних працівників у закладах вищої освіти України за освітніми ступенями «бакалавр» і «магістр» 32019 року здійснюють відповідно до затверджених стандартів вищої освіти (накази Міністерства освіти і науки України «Про затвердження стандарту вищої освіти за спеціальністю 231 «Соціальна робота» для першого (бакалаврського) рівня вищої освіти» №557 від 24.04.2019 р. та «Про затвердження стандарту вищої освіти за спеціальністю 231 «Соціальна робота» для другого (магістерського) рівня вищої освіти» №556 від 24.04.2019 р.), на основі яких розроблено освітні програми (Наказ Міністерства освіти і науки України про затвердження стандарту вищої освіти, 2019).

В Уманському державному педагогічному університеті імені Павла Тичини на факультеті соціальної та психологічної освіти підготовка майбутніх соціальних працівників до роботи 3 молоддю здійснюється за освітньо-професійною програмою «Соціальна робота (Молодіжна робота)» спеціальності 231 Соціальна робота освітнього ступеня «магістр». Усі вимоги Державного стандарту спеціальності 231 Соціальна робота дотримано освітньо-професійною програмою підготовки майбутніх соціальних працівників до молодіжної роботи («Соціальна робота (Молодіжна робота)»). 
Мета дослідження - проаналізувати специфіку освітньо-професійної програми «Соціальна робота (Молодіжна робота)» щодо підготовки майбутніх соціальних працівників до молодіжної роботи в Уманському державному педагогічному університеті імені Павла Тичини.

\section{Методологічна основа дослідження}

Для досягнення поставленої мети було застосовано теоретичний метод аналіз наукової літератури, нормативних документів, освітніх програм, навчальних планів, змісту робочих навчальних програм освітніх компонентів 3 метою їх структурування, узагальнення; скринінг Інтернет-сайтів ЗВО, що здійснюють підготовку майбутніх соціальних працівників до молодіжної роботи.

\section{Основна частина}

32018 року підготовку майбутніх соціальних працівників до молодіжної роботи здійснюе факультет соціальної та психологічної освіти Уманського державного педагогічного університету імені Павла Тичини. Гарант освітньопрофесійної програми «Соціальна робота (Молодіжна робота)» - д. пед. н, проф., декан факультету соціальної та психологічної освіти Кравченко О. О. Обсяг програми - 90 кредитів, термін навчання 1 рік і 4 місяці. Враховуючи галузевий та регіональний контекст, пропозиції роботодавців, випускників, здобувачів вищої освіти, науково-педагогічних працівників та ін. освітня програма постійно оновлюється.

В освітньо-професійній програмі Уманського державного педагогічного університету імені Павла Тичини «Соціальна робота (Молодіжна робота)» (2021) за спеціальністю 231 Соціальна робота освітнього ступеня «магістр» для підготовки майбутніх соціальних працівників до молодіжної роботи передбачено обов'язкові компоненти: «Молодь у сучасній громаді», «Проєктна діяльність у молодіжній роботі», «Теорія і практика молодіжної роботи»; а також вибіркові: «Молодіжна робота», «Молодіжна робота у сфері дозвілля та волонтерства», «Сучасні практики молодіжної роботи», «Організація та інфраструктура молодіжної роботи», «Соціальне проєктування в молодіжній роботі», «Тренінгові технології в молодіжній роботі», «Менеджмент молодіжної роботи» (Освітньопрофесійна програма Уманського державного педагогічного університету імені Павла Тичини, 2021).

Відповідно до освітньо-професійної програми визначено загальні й фахові компетентності та програмні результати, якими має володіти майбутніх соціальній працівник у молодіжній роботі під час вивчення обов'язкових дисциплін.

Навчальна дисципліна «Молодь у сучасній громаді»: загальні компетентності - здатність генерувати нові ідеї (креативність); фахові компетентності - уміння враховувати потреби та прагнення молодих людей; уміння забезпечувати можливості для навчання та розвитку молоді; здатність ініціювати та впроваджувати заходи в межах реалізації молодіжної політики України; уміння створювати умови для підвищення безпечності середовища $\mathrm{i}$ посилення життестійкості молоді; програмні результати навчання - уміння 
створювати умови для підвищення безпечності середовища i посилення життєстійкості молоді; уміння формувати навички здорового способу життя, розвиток та збереження фізичної культури, культури здорового харчування та психогігієни серед молоді; уміння підвищувати рівень участі молоді в суспільному житті, іiі конкурентоспроможність; уміння формувати в молоді громадянських компетентностей, навичок підвищення самостійності, мобільності, соціального та культурного включення в українське суспільство та світ; уміння підтримувати і сприяти розвиткові підприємницької ініціативи та діяльності молоді.

Навчальна дисципліна «Проєктна діяльність у молодіжній роботі»: загальні компетентності - здатність розробляти і управляти проєктами; здатність генерувати нові ідеї (креативність); здатність до міжособистісної взаємодії; фахові компетентності - здатність професійно діагностувати, прогнозувати, проєктувати та моделювати соціальні ситуації; здатність до впровадження методів і технологій інноваційного практикування та управління в системі соціальної роботи; здатність до оцінки процесу і результату професійної діяльності та якості соціальних послуг; здатність до розроблення, апробації та втілення соціальних проєктів і технологій; уміння оцінювати стан молодіжної роботи для покращення iї якості; здатність ініціювати та впроваджувати заходи 3 молодіжної політики України; програмні результати навчання - уміння розробляти соціальні проєкти на високопрофесійному рівні; уміння розробляти, апробувати та втілювати соціальні проекти і технології; уміння формувати в молоді навичок підвищення самостійності, мобільності, соціального та культурного включення в українське суспільство та світ.

Навчальна дисципліна «Теорія $і$ практика молодіжної роботи»: загальні компетентності - навички міжособистісної взаємодії; фахові компетентності здатність професійно діагностувати, прогнозувати, проєктувати та моделювати соціальні ситуації; здатність впроваджувати методи і технології інноваційного практикування та управління в системі соціальної роботи; здатність до професійної рефлексії; здатність виявляти професійну ідентичність та діяти згідно з цінностями соціальної роботи; уміння враховувати потреби та прагнення молодих людей; здатність підтримувати та розширювати можливості молоді в осмисленні суспільства; здатність підтримувати молодих людей в активному освоєнні міжкультурних відносин; уміння оцінювати якість молодіжної роботи для iï покращення; здатність ініціювати та впроваджувати заходи 3 реалізації молодіжної політики України; уміння створювати умови для підвищення безпечності середовища і посилення життєстійкості молоді; здатність формувати навички здорового способу життя, розвивати фізичну культуру, культуру здорового харчування та психогігієни; уміння підвищувати рівень участі молоді в суспільному житті, iii конкурентоспроможність, формувати у молоді громадянських компетентностей; здатність формувати в молоді навичок підвищення самостійності, мобільності, соціального та культурного включення в українське суспільство та світ; програмні результати навчання - вміння аналізувати соціальний та індивідуальний контекст проблем особи, сім'ї, соціальної групи, громади, формулювати мету і завдання соціальної роботи, 
планувати втручання в складних і непередбачуваних обставинах відповідно до цінностей соціальної роботи; уміння реалізовувати спільну та скоординовану діяльність органів державної влади та органів місцевого самоврядування у партнерстві з інститутами громадянського суспільства, установами, закладами та фахівцями, що працюють 3 молоддю; уміння підвищувати рівень участі молоді в суспільному житті, ऑii конкурентоспроможність, формування в молоді громадянських компетентностей; уміння формувати в молоді навичок підвищення самостійності, мобільності, соціального та культурного включення в українське суспільство та світ.

Проаналізувавши загальні та фахові компетентності, програмні результати, якими має володіти майбутній соціальний працівник для організації молодіжної роботи, визначені в освітній програмі, робочих програмах, силабусах обов'язкових компонентах, приходимо до висновку, що освітньо-професійна програма спрямована на підготовку висококваліфікованого фахівця у сфері молодіжної роботи.

Відповідно до кожної навчальної дисципліни науково-педагогічні працівники кафедри соціальної педагогіки та соціальної роботи факультету соціальної та психологічної освіти розробили навчально-методичні комплекси, до яких входять робочі навчальні програми, навчальні матеріали (комплекси лекцій 3 навчальної дисципліни, методичні рекомендації для проведення лабораторних, практичних та семінарських занять), методичні розробки з організації самостійної та індивідуальної роботи, засоби діагностики з навчальних дисциплін та ін.

Аналіз робочих програм дисциплін «Теорія і практика молодіжної роботи» та «Молодь в сучасній громаді» дав змогу визначити основні їх складові:

1) Опис навчальних дисииплін:

«Молодь в сучасній громадi» (кількість кредитів - 4, модулів - 2, змістових модулів - 2, загальна кількість годин - 120, аудиторних годин $-40,3$ них: 20 лекційних, 20 - практичних, самостійна робота - 40 год., індивідуальні завдання 40 год.);

«Теорія і практика молодіжної роботи» (кількість кредитів - 3, модулів 2, загальна кількість годин - 90, аудиторних годин - 40, 3 них - 20 - лекційних, 20 - практичних, самостійна робота - 30 год., індивідуальні завдання - 20 год.).

2) Мета та завдання навчальних дисциплін:

«Молодь у сучасній громаді» - підготовка висококваліфікованих фахівців за спеціальністю 231 Соціальна робота, забезпечення їх поглибленими спеціальними вміннями та знаннями теоретичних основ соціальної роботи 3 молоддю; найважливіших методів соціальної роботи 3 молоддю; особливостей соціальної роботи 3 молоддю в сім’і, у школі, 3 представниками молодіжних субкультур; технологій проведення масових молодіжних заходів.

Мета дисципліни «Теорія і практика молодіжної роботи» - забезпечення теоретичними, методичними і практичними знаннями та навиками здобувачів вищої освіти до молодіжної роботи; оволодіння знаннями, практичними вміннями і навичками організації молодіжної роботи.

3) Програми навчальних дисциплін містять тематику змістових модулів та їх наповнення. У програмі дисципліни «Молодь у сучасній громаді» 
виокремлено два змістових модулі «Соціальна робота в громадах як механізм реалізації молодіжної політики», «Соціальні технології роботи 3 молоддю в громаді», до яких входять 13 таких тем занять: Теоретичні основи соціальної роботи в громадах. Правові та етичні засади роботи в громадах. Основні напрямки соціальної роботи 3 молоддю. Діяльність установ органів у справах молоді. Соціальна допомога вразливим категоріям молоді. Сприяння зайнятості та працевлаштування молоді. Комплексна підтримка молодої сім'ї. Соціальна робота у сфері молодіжного дозвілля. Розвиток волонтерства в молодіжному середовищі. Інноваційні проєкти в соціальній роботі 3 молоддю. Гендерні особливості соціальної роботи з молоддю. Психотехнології в соціальній роботі 3 молоддю. Правові основи роботи з молоддю.

У програмі дисципліни «Теорія $і$ практика молодіжної роботи» - два змістових модулі «Теоретичний аспект молодіжної роботи», «Практичний аспект молодіжної роботи» та 8 навчальних тем занять: Ключові поняття «молодь», «молодіжна робота». Значення молодіжної політики в роботі 3 молоддю. Становлення молодіжної роботи. Напрями молодіжної роботи. Нормативноправове забезпечення молодіжної роботи. Молодіжна робота в країнах Європейського союзу. Участь молоді в заходах на різних рівнях держави. Практики молодіжної роботи.

4) Структура навчальних дисциплін. Навчальні дисципліни мають розподіл годин на лекційні, практичні, самостійну та індивідуальну роботу.

5) Самостійна робота здобувачів вищої освіти 3 дисциплін складається 3 таких видів робіт: підготовка до лекційних та практичних занять; опрацювання навчальної та додаткової літератури за темами; аналіз законодавчих актів; розробка проєкту молодіжної громадської організації та ін.; підготовка доповідей; підготовка до контрольних заходів; екзамену та заліку. У програмах вказані теми для самостійного опрацювання, кількість годин та інші вимоги.

6) Індивідуальна робота з дисципліни «Теорія $i$ практика молодіжної роботи» полягає в розробці та в комплектуванні «Портфоліо молодіжного працівника»; 3 дисципліни «Молодь у сучасній громаді» - розробка тренінгу активації молодіжної ініціативи.

7) Методи навчання. Методи організації навчально-пізнавальної діяльності (за джерелом інформації (словесні (лекція (традиційна, проблемна, лекція-пресконференція), пояснення, розповідь, бесіда)); наочні (спостереження, ілюстрація, демонстрація); практичні (вправи)); за логікою передачі і сприймання навчальної інформації (індуктивні, дедуктивні, аналітичні, синтетичні); за ступенем самостійності мислення (репродуктивні, пошукові, дослідницькі); за ступенем керування навчальною діяльністю (під керівництвом викладача; самостійна робота студентів: 3 книгою; виконання індивідуальних навчальних проектів)); методи стимулювання інтересу до навчально-пізнавальної діяльності (навчальні дискусії (групове обговорення); створення ситуації пізнавальної новизни; створення ситуації зацікавленості (метод цікавих аналогій тощо)).

8) Для всіх дисциплін є однакові методи контролю: індивідуальне та фронтальне опитування, співбесіда, модульне та підсумкове письмове тестування, іспит, письмові роботи (звіт, есе), оцінка результатів виконання завдань для 
самостійної роботи, індивідуальні навчально-дослідні завдання (підготовка реферату, розробка індивідуальних навчальних проєктів та їх презентація групі, обговорення результатів роботи, розробка відеопрезентацій), оцінка студентами результатів власної роботи та роботи інших студентів.

9) Результати навчання оцінюються за загальними критеріями для всіх навчальних дисциплін закладу вищої освіти, а саме:

5 балів - оцінюють роботу студента, який у повному обсязі володіє навчальним матеріалом, вільно, самостійно та аргументовано його викладає, глибоко та всебічно розкриває зміст теоретичних запитань та практичних завдань, використовуючи при цьому обов'язкову та додаткову літературу, вільно послуговується науковою термінологією, розв'язує задачі стандартним або оригінальним способом, наводить аргументи на підтвердження власних думок, здійснює аналіз та робить висновки.);

4 бали - оцінюють роботу студента, який володіє навчальним матеріалом, обгрунтовано його викладає, в основному розкриває зміст теоретичних запитань та практичних завдань, використовуючи при цьому обов’язкову літературу, розв'язує задачі стандартним способом, використовує наукову термінологію, але при висвітленні деяких питань студентові не вистачає достатньої глибини та аргументації, допускає при цьому окремі неістотні неточності та незначні помилки;

3 бали - оцінюють роботу студента, який відтворює значну частину навчального матеріалу, висвітлює його основний зміст, виявляє елементарні знання окремих положень, записує основні формули, рівняння, закони. Студент не здатний до глибокого, всебічного аналізу, обгрунтування та аргументації, не використовує необхідну літературу, допускає істотні неточності та помилки;

2 бали - оцінюють роботу студента, який не володіє навчальним матеріалом у достатньому обсязі, проте фрагментарно, поверхово (без аргументації та обгрунтування) викладає окремі питання навчальної дисципліни, не розкриває зміст теоретичних питань і практичних завдань;

1 бал- оцінюють роботу студента, який не в змозі викласти зміст більшості питань теми та курсу, володіє навчальним матеріалом на рівні розпізнавання явищ, допускає істотні помилки, відповідає на запитання, що потребують однослівної відповіді;

0 балів - оцінюють роботу студента, який не володіє навчальним матеріалом та не в змозі його висвітлити, не розуміє змісту теоретичних питань та практичних завдань.).

10) Розподіл балів з дисиипліни «Теорія $і$ практика молодіжної роботи» загальна сума балів за семестр, які може отримати за свою роботу студент - 100, 3 них: виконання практичних занять -80 балів сюди ж входять бали за виконання самостійної роботи; за виконання контрольних - 10 балів та індивідуальне завдання - 10 балів; 3 дисципліни «Молодь у сучасній громаді» здобувач може отримати за курс загальну кількість балів - 100, 3 них: 78 балів за виконання практичних занять та самостійну роботу, за індивідуальну роботу - 12 балів, за екзамен - 10 балів. 
11) Методичне забезпечення. До кожної дисципліни укладено навчальну та робочу навчальну програми, силабуси, навчальні посібники для виконання практичних завдань із лекційними матеріалами; методичні рекомендації для виконання завдань для самостійної роботи.

12) Рекомендовану літературу підібрано відповідно до лекційних і практичних занять із дисциплін, та для виконання самостійної роботи. Вона містить основні, допоміжні джерела та інформаційні ресурси для підготовки до занять (Робочі навчальні програми дисциплін, 2020, 2021).

\section{Висновки}

Проаналізувавши освітньо-професійну програму, робочі навчальні програми підготовки майбутніх соціальних працівників до молодіжної роботи в закладі вищої освіти, висновковуємо, що обов'язкові навчальні компоненти сприяють активізації знань в майбутніх фахівців про основні поняття молодіжної сфери; виявленню значення молодіжної політики для роботи 3 молоддю, визначенню основних напрямів молодіжної роботи, форм участі молоді у різних заходах на місцевому, регіональному, державному рівнях; формуванню вмінь:

- враховувати потреби та прагнення молодих людей; забезпечувати можливості для навчання молоді; підтримувати та розширювати можливості молоді в осмисленні суспільства, у якому вони живуть, і взаємодії з ним;

- підтримувати молодих людей в активному й конструктивному освоєнні міжкультурних відносин;

- активно практикувати оцінювання з метою покращення якості молодіжної роботи;

- підтримувати колективне навчання в командах.

Перспективним вважаємо вдосконалення та впровадження в освітній процес підготовки майбутніх соціальних працівників до молодіжної роботи вибіркових освітніх компонентів, у яких закладені сучасні технології молодіжної роботи, проєктна діяльність, менеджмент молодіжних центрів, волонтерська та дозвіллєва діяльність у молодіжній роботі; а також моніторинг рівня засвоєння компетентностей у здобувачів вищої освіти.

\section{Література}

Коляда, Н.М., Левченко, Н.В., Ісаченко, В.П. (2020). Підготовка фахівців до роботи $з$ молоддю: історичний аспект. Науковий вісник Ужгородського університету. Серія: «Педагогіка. Соиіальна робота». Випуск 2(47). С. 61 - 66. https://doi.org/10.24144/25240609.2020.47.61-66 URL: https://dspace.uzhnu.edu.ua (дата звернення 29.06.2021).

Kravchenko, O., Koliada, N., Levchenko, N. (2020) Youth Workers and Innovative Development of Social Work. In: Kantola J., Nazir S., Salminen V. (eds) Advances in Human Factors, Business Management and Leadership. AHFE 2020. Advances in Intelligent Systems and Computing, vol 1209. Springer, Cham. https://doi.org/10.1007/978-3-030-50791-6 54 (дата звернення 29.06.2021).

Наказ Міністерства освіти і науки України «Про затвердження стандарту вищої освіти за спеціальністю 231 «Соціальна робота» для другого (магістерського) рівня вищої освіти» №556 від 24.04.2019 p. URL: https://mon.gov.ua/storage (дата звернення 29.06.2021).

Освітньо-професійна програма Уманського державного педагогічного університету імені Павла Тичини «Соціальна робота (Молодіжна робота)» другого (магістерського) рівня 
вищої освіти спеціальності 231 Соціальна робота (2021). URL: https://fspo.udpu.edu.ua (дата звернення 29.06.2021).

Робоча навчальна програма дисципліни «Молодь в сучасній громаді» освітньопрофесійної програми «Соціальна робота (Молодіжна робота)» Уманського державного педагогічного університету імені Павла Тичини спеціальності 231 Соціальна робота, 2020. 15 с.

Робоча навчальна програма дисципліни «Теорія і практика молодіжної роботи» освітньо-професійної програми «Соціальна робота (Молодіжна робота)» Уманського державного педагогічного університету імені Павла Тичини спеціальності 231 Соціальна робота, 2020. $15 \mathrm{c}$.

Слозанська, Г. (2016). Професійна підготовка майбутніх соціальних працівників у вищих навчальних закладах на основі застосування контекстного підходу. Збірник наукових праць. Випуск 21 (2 - 2016). Частина 1. URL: http://ped.kpnu.edu.ua (дата звернення 29.06.2021). 


\section{CONTENTS OF TRAINING OF FUTURE YOUTH WORK SOCIAL WORKERS: FROM THE EXPERIENCE OF UMAN STATE PEDAGOGICAL UNIVERSITY}

Nataliia Levchenko, Candidate of Pedagogical Sciences, Associate Professor of Social Pedagogy and Social Work, Doctoral Student Pavlo Tychyna Uman State Pedagogical University, Uman, Ukraine; n.levchenkod@gmail.com

Abstract. The relevance of the study is that modern youth is the subject of special attention of modern society, because the change of socio-economic and political system of Ukraine has had an ambiguous impact on the consciousness and behavior of the younger generation. Today, democratic processes are observed in various spheres of life, civil society is being developed, and opportunities for personal development, initiative and creativity are being provided. The future of the state largely depends on the civic position of the younger generation, this fact increases the importance of managing the processes of national-patriotic formation of future youth work social workers in the process of studying in a higher education institution. The purpose of the article is to analyze the specifics of the educational and professional program "Social Work (Youth Work)" to prepare future youth work social workers at Pavlo Tychyna Uman State Pedagogical University. Research methods: systematic, problem-targeted, normative-comparative analysis of sources; content analysis of documentation, educational programs, curricula, content of active educational programs of educational components; screening of websites of higher education institutions that train future social workers for youth work. The article highlights the relevance of the introduction in the educational process of training future youth work social workers such disciplines as "Theory and practice of youth work", "Youth in the modern community"; the content and structure of compulsory educational components of the educationalprofessional program "Social work (Youth work)" are revealed; methods of teaching and learning, criteria for evaluating learning outcomes of a program are presented; general and professional competencies and learning outcomes of a program are regulated and analyzed - regulated by academic disciplines. The peculiarities of the educational program for the preparation of future youth work social workers from the experience of the Faculty of Social and Psychological Education of Pavlo Tychyna Uman State Pedagogical University are determined.

Keywords: future social workers; youth workers; youth work; educational and professional program; social work. 


\section{References}

Koliada, N. M., Levchenko, N. V., Isachenko, V. P. (2020) Training professionals to work with youth: a historical aspect. Scientific Bulletin of Uzhhorod University. Series: "Pedagogy. Social work". Issue 2 (47). Pp. 61-66. https://doi.org/10.24144/25240609.2020.47.61-66 URL: https://dspace.uzhnu.edu.ua [in Ukrainian].

Kravchenko, O., Koliada, N., Levchenko, N. (2020) Youth Workers and Innovative Development of Social Work. In: Kantola J., Nazir S., Salminen V. (eds) Advances in Human Factors, Business Management and Leadership. AHFE 2020. Advances in Intelligent Systems and Computing, vol 1209. Springer, Cham. https://doi.org/10.1007/978-3-030-50791-6_54

Order of the Ministry of Education and Science of Ukraine "On approval of the standard of higher education in the specialty 231 "Social work" for the second (master's) level of higher education” №556 from 24.04.2019 URL: https://mon.gov.ua/storage/app/media/vishchaosvita/zatverdzeni\%20standarty/2019/05/06/231-sotsialna-robota-magistr.pdf [in Ukrainian].

Educational and professional program of Pavlo Tychyna Uman State Pedagogical University "Social work (Youth work)" of the second (master's) level of higher education, specialty 231 Social work (2021). URL: https://fspo.udpu.edu.ua [in Ukrainian].

Working curriculum of the discipline "Youth in the modern community" of the educational-professional program "Social work (Youth work)" of Pavlo Tychyna Uman State Pedagogical University, specialty 231 Social work, 2020. 15 p. [in Ukrainian].

Working curriculum of the discipline "Theory and Practice of Youth Work" of the educational-professional program "Social Work (Youth Work)" of Pavlo Tychyna Uman State Pedagogical University, specialty 231 Social Work, 2020. 15 p. [in Ukrainian].

Slozanska, G. (2016). Professional training of future social workers in higher education institutions based on the application of a contextual approach. Collection of scientific works. Issue 21 (2 - 2016). Part 1. URL: http://ped.kpnu.edu.ua [in Ukrainian].

\section{Article history:}

Received: August 05, 2021

1st Revision: September 07, 2021

Accepted: September 30, 2021 